\title{
Georges Couthon: A Paralysed Lawyer and Leader of the French Revolution
}

A. Ohry, MD, K. Ohry-Kossoy, MA

Neurological Rehabilitation Department, Sheba Medical Center, Tel Hashomer, Israel.

Key words: Georges Couthon; History of medicine; French Revolution; Paraplegia; Rehabilitation.

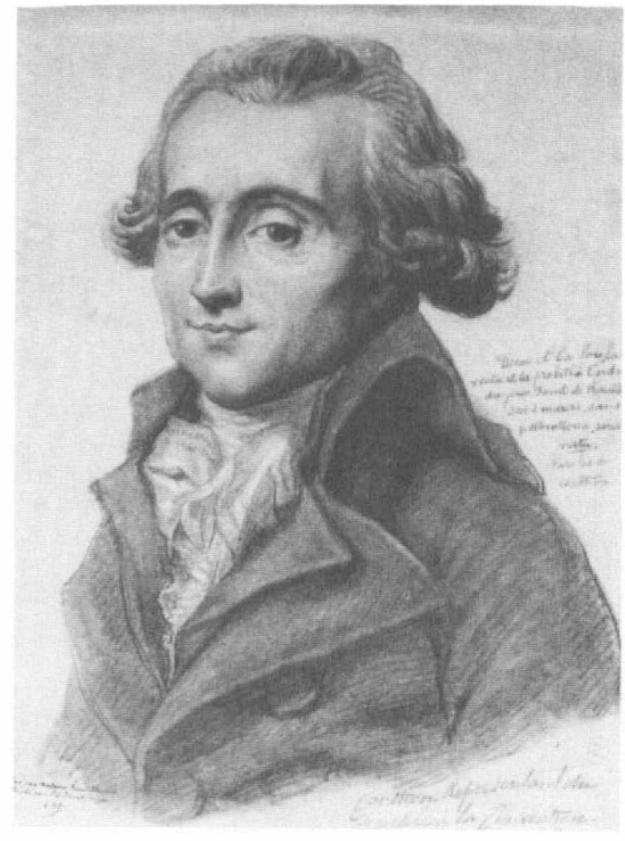

Two hundred years exactly have passed since one of mankind's great upheavals, the French Revolution (Carlyle, 1857). Almost every aspect of the nation's life was touched by it, and some domains underwent very deep changes: politics; the social order; the sciences. In medicine some old dogmas were discarded, new methods were tried, teaching was reformed (Chevalier, 1940). Modern 
rehabilitation was still a century and a half away, but among the significant figures of the Revolution there was a paralysed lawyer whose severe disability did not prevent him from having a short yet extremely active political career.

In June 1794, 5 years after its beginning, the Revolution was in the stage called 'Terror', in which yesterday's revolutionary heroes became today's victims of the guillotine, one political faction killing off another (Jordan, 1985; Mignet, 1939; Renier, 1896; Rude, 1967). In July of that year Robespierre, one of the Revolution's main leaders, was thus executed with his friends, Georges Couthon among them. Couthon was 39 years old. How had this paralysed man managed to live a thriving political and personal life in that stormy period? (Couthon, 1872, 1974; Greenhough-Smith, 1928).

Georges Couthon was born near the town of Clermont-Ferrand, where he became a respected lawyer and later president of the tribunal. In 1791 he went to Paris to represent Clermont-Ferrand at the Revolution's Legislative Assembly, joining the radical Jacobin party. As delegate to the National Convention which succeeded the Legislative Assembly Couthon voted with the majority in favour of King Louis XVI's death. Although he was by then confined to a wheelchair, he was sent on several important missions to the French provinces. He always remained utterly loyal to his constituents, writing to them about each of his political moves, but above all obtaining public financing and vital supplies for the district of Clermont-Ferrand.

At the National Convention Couthon spoke and acted against the moderate Girondin delegates. He became a member of the ruling Committee of Public Safety and helped to draft a new French constitution. In August 1793, he was sent to supervise the military operations against the rebellious city of Lyons, which not only proves his strong political status at the time, but also shows that his disability was not considered to be an obstacle by himself or by those surrounding him. Lyons surrendered a couple of months later. Couthon, however, managed to have himself removed from his post in order to let someone else mercilessly punish the city as the Convention had decreed (Gagnon, 1964; Gottschalk, 1929).

In 1794 he helped Robespierre and Saint-Just bring down their opponents Hébert and Danton, and was instrumental in starting the blood-smeared Reign of Terror. Robespierre faced growing opposition. Couthon had again been chosen for an important mission to the provinces, and could have saved his own life by leaving Paris. Out of loyalty to Robespierre he decided to stay. He was arrested and executed as he had lived, without regard for his disability.

It is said that Danton, shortly before he was executed, pronounced the following words: 'If I left my legs to Couthon the Committee of Public Safety might stagger on a bit longer' (Christopher, 1965). Although we have not found actual medical documents about Couthon, there is sufficient material from himself and by others to attempt a description of this spinal case. Couthon was 32 when he married a childhood friend in 1787 and his first son was born in that same year. It appears that he started having pains around that time. A year or two later his legs became paralysed. His second son was born at least 1 year later. Couthon required to be carried or to use a wheelchair, He suffered from weakness, pain, and had a gibbous deformity. Despite his worsening condition Couthon's sexual and reproductive functions remained unimpaired. His 
disability did not prevent him from work, political activity, travels and family life to the end (Couthon, 1872).

The aetiology of Couthon's illness is very uncertain. One story has it that his problem was due to romantic circumstances and started after a night spent in a frozen peatbog (Carlyle, 1857). This kind of trauma on its own could have caused peripheral neuropathy or vascular ischaemic damage to the limbs, but not paralysis.

On the other hand, Couthon's family, denying this version, stated that his disability appeared after a very hot prolonged bath at a French spa where he had sought to relieve his pains (Huard, 1970). This would rather point to meningitis or myelitis, of viral, bacterial, syphilitic or tubercular origin; or to multiple sclerosis. He may also have suffered from a combination of trauma and disease.

Whatever the causes, the range of possible treatments for this type of condition was at that time limited. Couthon tried electrotherapy, mineral spring waters, mudbaths, a milk diet, all to no avail. He died only about 6 years after the onset of his condition, too soon for a natural history of a possible disease.

Couthon did not always extend to other unfortunates the fairness with which he was treated. It is said that when Philippe Pinel, a founder of modern psychiatry, wanted to set free the deaf, retarded or mentally sick patients of a Paris asylum, Couthon, fearing some counter-revolutionaries might be hiding among them, warned him against it with these words: 'Méfie-toi, citoyen Pinel' beware, citizen Pinel.

\section{References}

Carlyle T 1857 The French Revolution-A History. The Modern Library, Random House, New York, p 392.

Chevalier AG 1940 Le rôle des médecins pendant la révolution française. Revue Ciba 1: 322-353.

Christopher R 1965 Danton-A Biography. Translated by P. Green. Arthur Barber, London.

Couthon G 1974 In: Encyclopaedia Britannica, vol 3, 15th edn. Chicago-London.

GAGNON PA 1864 France Since 1789. Harper \& Row, New York, pp 21-39.

GotTSCHALK LR 1929 The Era of the French Revolution (1715-1815). Houghton, Mittlin, Riberside Press, Cambridge, Boston, New York, pp 230-264.

Greenhough-Smith H 1928 G. Couthon. In: Romances of History. George Newnes, London, pp 55-61.

HuARD P 1970 Sciences, Médecine, Pharmacie de la Révolution à l'Empire (1789-1815). Roger Da Costa, Paris, pp 196-197.

JoRDAN DP 1985 The Revolutionary Career of Max Robespierre. Free Press (Macmillan), New York.

Mignet FAM 1939 The History of the French Revolution. JM Dent \& Sons, London, pp 220-242.

RENIER GJ 1936 Robespierre. Thomas Nelson \& Sons, London, pp 105-167.

Rude G 1967 Robespierre. Prentice-Hall, New Jersey, pp 140-153. 